\title{
X-linked recessive ocular albinism
}

INSERM

\section{Source}

INSERM. (1999). Orphanet: an online rare disease and orphan drug data base. $\underline{X \text {-linked }}$ recessive ocular albinism. ORPHA:54

X-linked recessive ocular albinism (XLOA) is a rare disorder characterized by ocular hypopigmentation, foveal hypoplasia, nystagmus, photodysphoria, and reduced visual acuity in males. 